\title{
Reactions of 3-phenyl-1,2,4-triazine with some C-nucleophiles
}

\author{
Yurii A. Azev, ${ }^{* a}$ Ol'ga S. Ermakova, ${ }^{a}$ Mikhail I. Kodess, ${ }^{b}$ \\ Marina A. Ezhikova, ${ }^{b}$ Igor S. Kovalev $^{a}$ and Vasiliy A. Bakulev ${ }^{a}$ \\ ${ }^{a}$ Department of Organic Chemistry, Ural Federal University, 620002 Ekaterinburg, Russian Federation. \\ Fax:+7 343375 4135; e-mail: azural@yandex.ru,azural@mail.ustu.ru \\ ${ }^{b}$ I. Ya. Postovsky Institute of Organic Synthesis, Ural Branch of the Russian Academy of Sciences, \\ 620990 Ekaterinburg, Russian Federation.E-mail:nmr@ios.uran.ru
}

DOI: $10.1016 /$ j.mencom.2013.09.020

Dimedone is added at $\mathrm{C}(5)$ of 3-phenyl-1,2,4-triazine to give stable dihydro derivative. Its reaction with 1-aryl-3-methylpyrazol-5ones proceeds with fragmentation affording 1,1,2,2-tetrakispyrazolylethane and amidrazone derivatives.

The triazine ring is present in a number of natural and synthetic physiologically active compounds, ${ }^{1}$ therefore studies of their chemical modification are promising. $\mathrm{CH}$-acids such as acetylacetone, phenylacetone and acetophenone are added to 6-methyl3-phenyl-1,2,4-triazine in the presence of sodium hydride to give adducts that are readily oxidized with oxygen to produce stable 5-substituted 6-methyl-3-phenyl-1,2,4-triazines. ${ }^{2}$ An addition of two indole molecules to 1-alkyl-1,2,4-triazinium salts results in 5,6-diindolyl $\sigma$-adducts. ${ }^{3}$ Acetoacetic amides react with quaternary and protic salts of 1,2,4-triazine to form bisadducts with annelation of the pyrrole ring at the $\mathrm{C}^{5}-\mathrm{C}^{6}$ bond of the triazine ring. ${ }^{4}$ In some cases, hydrogen replacement in 1,2,4-triazines allows one to perform their smooth functionalization. However, even now there are no unambiguous criteria for determining the direction of nucleophilic attack and the depth of conversion of these compounds if various methods of reagent activation and various nucleophile types are used. Moreover, reactions of as-triazines with pyrazol-5-ones as C-nucleophiles have not been studied.

Herein, we have discovered that 3-phenyl-1,2,4-triazine $\mathbf{1}$ smoothly reacts with dimedone in DMSO in the presence of an acid (or a base) at room temperature to give stable 5- $\sigma$-adduct 2 (Scheme 1) ${ }^{\dagger}$

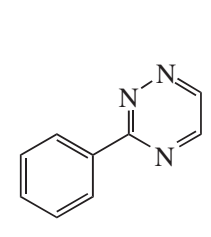

1
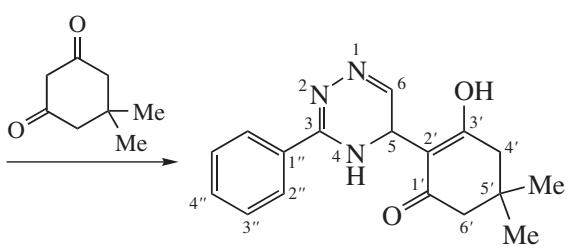

2
Scheme 1

$\uparrow$ 5,5-Dimethyl-2-(3-phenyl-1,4-dihydro-1,2,4-triazin-5-yl)cyclohexane1,3-dione 2. A mixture of 3-phenyl-1,2,4-triazine $\mathbf{1}(0.075 \mathrm{~g}, 0.48 \mathrm{mmol})$ and dimedone $(0.070 \mathrm{~g}, 0.50 \mathrm{mmol})$ was kept in DMSO $(1 \mathrm{ml})$ in the presence of concentrated $\mathrm{HCl}(0.1 \mathrm{ml})$ at room temperature for $48-50 \mathrm{~h}$. The reaction mixture was diluted with water $(1: 1)$ and adjusted to $\mathrm{pH}$ 6-7 with $15 \%$ aqueous ammonia. The precipitate formed was filtered off and recrystallized from aqueous ethanol to give $0.090 \mathrm{~g}(63 \%)$ of product $\mathbf{2}$, $\mathrm{mp} 168-169^{\circ} \mathrm{C} .{ }^{1} \mathrm{H}$ NMR $\left(500.1 \mathrm{MHz}, \mathrm{DMSO}-d_{6}\right) \delta: 1.00(\mathrm{~s}, 6 \mathrm{H}, 2 \mathrm{Me})$, 2.12-2.05 (AB system, 4 H, $\left.\mathrm{H}^{4^{\prime}}, \mathrm{H}^{6^{\prime}}\right), 4.96\left(\mathrm{~d}, 1 \mathrm{H}, \mathrm{H}^{5}, J 2.4 \mathrm{~Hz}\right), 6.75(\mathrm{~d}$, $\left.1 \mathrm{H}, \mathrm{H}^{6}, J 2.4 \mathrm{~Hz}\right), 7.56\left(\mathrm{dd}, 2 \mathrm{H}, \mathrm{H}^{3 "}, J 8.4\right.$ and $\left.7.5 \mathrm{~Hz}\right), 7.65\left(\mathrm{tt}, 1 \mathrm{H}, \mathrm{H}^{4 "}\right.$, $J 7.5$ and $1.4 \mathrm{~Hz}$ ), 7.71 (dd, $2 \mathrm{H}, \mathrm{H}^{2 "}, J 8.4$ and $1.4 \mathrm{~Hz}$ ), 12.5-11.0 (br. s, $2 \mathrm{H}, \mathrm{NH}, \mathrm{OH}) .{ }^{13} \mathrm{C}$ NMR $\left(125.7 \mathrm{MHz}, \mathrm{DMSO}-d_{6}\right) \delta: 28.45(2 \mathrm{Me}), 31.33$ $\left(C^{5^{\prime}}\right), 46.84\left(\mathrm{C}^{5}\right), 49.10\left(\mathrm{C}^{4^{\prime}}, \mathrm{C}^{6^{\prime}}\right), 107.46\left(\mathrm{C}^{2}\right), 127.64\left(\mathrm{C}^{2^{\prime \prime}}\right), 127.91\left(\mathrm{C}^{1^{\prime \prime}}\right)$, $128.87\left(\mathrm{C}^{3 \prime}\right), 132.69\left(\mathrm{C}^{4 \prime}\right), 143.37$ (br. s, $\left.\mathrm{C}^{6}\right), 153.55\left(\mathrm{C}^{3}\right), 187.59\left(\mathrm{C}^{1^{\prime}}\right.$, $\left.\mathrm{C}^{3}\right)$. HRMS (ESI), $m / z: 296.1406[\mathrm{M}-\mathrm{H}]^{-}$(calc. for $\mathrm{C}_{17} \mathrm{H}_{18} \mathrm{~N}_{3} \mathrm{O}_{2}, \mathrm{~m} / z$ : 296.1405).

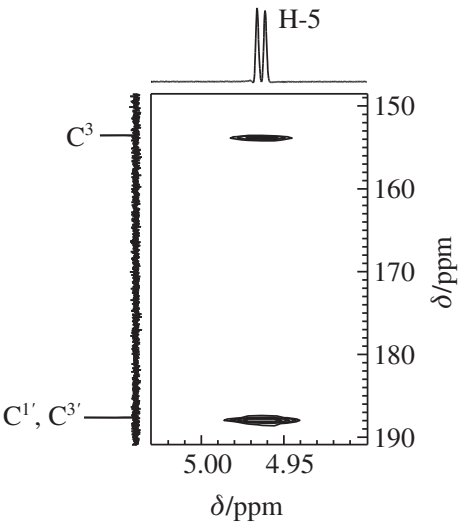

Figure 1 Fragment of a $2 \mathrm{D}{ }^{1} \mathrm{H}_{-}{ }^{13} \mathrm{C} \mathrm{HMBC}$ spectrum (500 MHz, DMSO- $d_{6}$ ) of compound 2 .

The structure of product 2 was confirmed by ${ }^{1} \mathrm{H}$ and ${ }^{13} \mathrm{C}$ NMR spectra and $2 \mathrm{D}{ }^{1} \mathrm{H}-{ }^{13} \mathrm{C}$ HSQC, HMBC experiments. Its ${ }^{1} \mathrm{H}-{ }^{13} \mathrm{C}$ HMBC spectrum (Figure 1) displays cross-peaks between the doublet of the $\mathrm{H}^{5}$ proton $(\delta 4.96, J 2.4 \mathrm{~Hz})$ and the $\mathrm{C}^{1^{\prime}}, \mathrm{C}^{3}$ $(\delta 187.59 \mathrm{ppm})$ and $\mathrm{C}^{3}$ carbon atoms $(\delta 153.55 \mathrm{ppm})$. In turn, assignment of the latter is confirmed by correlations with the ortho-protons of the phenyl substituent.

The ${ }^{1} \mathrm{H}$ and ${ }^{13} \mathrm{C}$ spectra of adduct 2 in DMSO- $d_{6}$ matches a structure with fast tautomeric transition between two enol forms of dimedone resulting in averaged shifts of protons and carbons in the dimedone moiety. The resonances of protons $\mathrm{H}^{5}(\delta 4.96 \mathrm{ppm})$ and $\mathrm{H}^{6}$ $(\delta 6.75 \mathrm{ppm})$ coupled by spin-spin interaction are characteristic.

Unusual transformations occurred during the reaction of 3-phenyl-1,2,4-triazine 1 with 1-aryl-3-methylpyrazol-5-ones 3a,b (Scheme 2): 1,1,2,2-tetrakis(5-methyl-2-oxo-2-phenyl1,2-dihydro-3H-pyrazol-4-yl)ethanes $\mathbf{4 a , b}$ were obtained at room temperature in DMSO in the presence of base.

\footnotetext{
* Reaction of 3-phenyl-1,2,4-triazine 1 with 3-methyl-1-phenylpyrazol5-ones 3a,b. A mixture of compound $\mathbf{1}(0.40 \mathrm{mmol})$, the corresponding 1-aryl-3-methyl-pyrazol-5-one $\mathbf{3}(1.60 \mathrm{mmol})$ and triethylamine $(0.1 \mathrm{ml})$ in DMSO $(1 \mathrm{ml})$ was kept at room temperature for $48 \mathrm{~h}$. The reaction mixture was diluted with water $(1: 1)$ and acidified to $\mathrm{pH} 5-6$ with $15 \%$ aqueous $\mathrm{HCl}$. The resulting precipitate was filtered off and washed with ethanol $(5 \mathrm{ml})$ at $55-60^{\circ} \mathrm{C}$. The residue on the filter was compound $\mathbf{4 a}, \mathbf{b}$. The ethanolic washings were evaporated to dryness in vacuo. The solid was treated with chloroform $(5 \mathrm{ml})$ and insoluble admixtures were filtered off. The mother liquor was evaporated in vacuo to give amidrazones 5 .

Compound $4 \mathbf{a}$, yield $50-55 \%$. Its melting point and ${ }^{1} \mathrm{H}$ NMR spectra are identical to those of tetrapyrazolylethane derivative reported earlier. ${ }^{5}$
} 

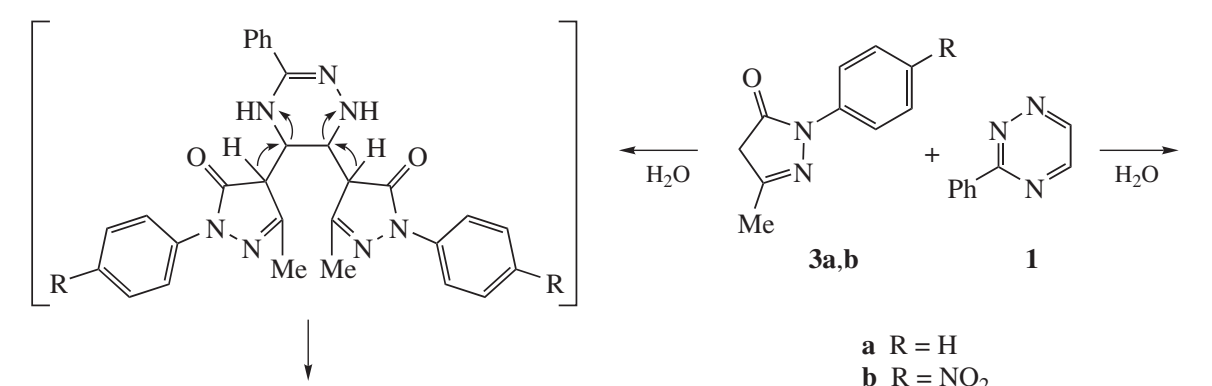<smiles>[R]c1ccc(N2N=C(C)C(=C3NN=C(C)NC3O)C2=O)cc1</smiles><smiles>[R]c1ccc(N2N=C(C)/C(=C\C=C3\C(=O)N(c4ccc([R])cc4)N=C3C)C2=O)cc1</smiles>
a $\mathrm{R}=\mathrm{H}$ b $\mathrm{R}=\mathrm{NO}_{2}$<smiles>[R]c1ccc(-n2nc(C)c(C(c3c(C)nn(-c4ccc([R])cc4)c3C(C)c3c(C)[nH]n(-c4ccc([R])cc4)c3=O)c3c(C)[nH]n(-c4ccc([R])cc4)c3=O)c2O)cc1</smiles><smiles>[R]c1ccc(N2N=C(C)/C(=C/N([Tl])N=C(N)c3ccccc3)C2=O)cc1</smiles><smiles>[R]c1ccc(N2N=C(C)C(=C(C=O)NN=C(N)c3ccccc3)C2=O)cc1</smiles><smiles>[R]c1ccc(N2N=C(C)C(C3(C=O)NN=C(CC)N3)C2=O)cc1</smiles>

B

Scheme 2

Product $4 \mathbf{a}$ is identical in the melting point and spectral characteristics to that reported previously. ${ }^{5}$ The high-resolution mass spectrum (ESI) of compound $\mathbf{4 b}$ reveals a molecular ion peak: $899.2468[\mathrm{M}+\mathrm{H}]^{+}$(calc. for $\mathrm{C}_{42} \mathrm{H}_{35} \mathrm{~N}_{12} \mathrm{O}_{12}: 899.2492$ ). Its ${ }^{1} \mathrm{H}$ NMR spectrum contains a characteristic two-proton singlet of ethane bridge at $\delta 4.73 \mathrm{ppm}$, as well as all appropriate signals of protons of the pyrazolone moieties.

In addition to products $\mathbf{4}$, amidrazones $\mathbf{5 a}, \mathbf{b}$ were also obtained. In their HRMS (ESI) spectra molecular ion peaks with the proper molecular masses are observed.

It is interesting that the two singlets in the ${ }^{1} \mathrm{H}$ NMR spectrum of compound $\mathbf{5 a}$ at $\delta_{\mathrm{H}} 9.02$ and $8.58 \mathrm{ppm}$ correspond to nonequivalent protons at one nitrogen atom, $\mathrm{N}^{10}\left(\delta_{\mathrm{N}} 99.0 \mathrm{ppm}\right)$. This

1,2-Bis[5-hydroxy-3-methyl-1-(4-nitrophenyl)-1H-pyrazol-4-yl]-1,2-bis[5-methyl-2-(4-nitrophenyl)-3-oxo-1,2-dihydropyrazol-4-yl]ethane $\mathbf{4 b}$ : yield $55-60 \%, \mathrm{mp}>250^{\circ} \mathrm{C} .{ }^{1} \mathrm{H}$ NMR $\left(400 \mathrm{MHz}, \mathrm{DMSO}-d_{6}\right) \delta: 2.22(\mathrm{~s}, 12 \mathrm{H}$, $4 \mathrm{Me}), 4.73\left(\mathrm{~s}, 2 \mathrm{H}, \mathrm{CH}_{\text {aliph }}\right), 8.04\left(\mathrm{~d}, 8 \mathrm{H}, J 8.8 \mathrm{~Hz}, \mathrm{CH}_{\text {arom }}\right), 8.22(\mathrm{~d}, 8 \mathrm{H}$, $\mathrm{CH}_{\text {arom }}, J 8.8 \mathrm{~Hz}$ ), 14.20 [br. s, $\left.2 \mathrm{H}, \mathrm{OH}(\mathrm{NH})\right]$. HRMS (ESI), $\mathrm{m} / z: 899.2468$ $[\mathrm{M}+\mathrm{H}]^{+}$(calc. for $\mathrm{C}_{42} \mathrm{H}_{35} \mathrm{~N}_{12} \mathrm{O}_{12}, \mathrm{~m} / z:$ : 899.2492).

$\mathrm{N}^{\prime}$-[(Z)-(3-Methyl-5-oxo-1-phenyl-1,5-dihydro-4H-pyrazol-4-ylidene)methyl]benzenecarbohydrazonamide 5a. Yield 20-25\%, mp 108-110 ${ }^{\circ} \mathrm{C}$. ${ }^{1} \mathrm{H}$ NMR $\left(500 \mathrm{MHz}, \mathrm{DMSO}-d_{6}\right) \delta: 2.17(\mathrm{~s}, 3 \mathrm{H}, \mathrm{Me}), 7.07\left(\mathrm{tt}, 1 \mathrm{H}, \mathrm{H}^{4^{\prime}}\right.$, $J 7.4$ and $1.1 \mathrm{~Hz}), 7.25\left(\mathrm{~s}, 1 \mathrm{H}, \mathrm{H}^{6}\right), 7.33\left(\mathrm{dd}, 2 \mathrm{H}, \mathrm{H}^{3}, J 8.5\right.$ and $\left.7.4 \mathrm{~Hz}\right)$, $7.64\left(\mathrm{t}, 2 \mathrm{H}, \mathrm{H}^{3 \prime \prime}, J 7.7 \mathrm{~Hz}\right), 7.71\left(\mathrm{tt}, 1 \mathrm{H}, \mathrm{H}^{4 \prime}, J 7.4\right.$ and $\left.1.2 \mathrm{~Hz}\right), 7.92(\mathrm{~m}$, $\left.4 \mathrm{H}, \mathrm{H}^{2}, \mathrm{H}^{2 \prime}\right), 8.58\left(\mathrm{~s}, 1 \mathrm{H}, \mathrm{H}^{10 \mathrm{~b}}\right), 9.02\left(\mathrm{~s}, 1 \mathrm{H}, \mathrm{H}^{10 \mathrm{a}}\right), 17.46\left(\mathrm{~s}, 1 \mathrm{H}, \mathrm{H}^{7}\right)$. ${ }^{13} \mathrm{C}$ NMR (126 MHz, DMSO- $\left.d_{6}\right) \delta: 12.83(\mathrm{Me}), 98.29\left(\mathrm{C}^{4}\right), 118.68\left(\mathrm{C}^{2}\right)$, $123.42\left(\mathrm{C}^{4^{\prime}}\right), 127.54\left(\mathrm{C}^{2^{\prime \prime}}\right), 127.82\left(\mathrm{C}^{1^{\prime \prime}}\right), 128.42\left(\mathrm{C}^{3^{\prime}}\right), 129.12\left(\mathrm{C}^{3^{\prime \prime}}\right), 132.94$ $\left(\mathrm{C}^{4 \prime}\right), 139.98\left(\mathrm{C}^{1}\right), 145.30\left(\mathrm{C}^{6}\right), 148.50\left(\mathrm{C}^{3}\right), 156.35\left(\mathrm{C}^{9}\right), 161.56\left(\mathrm{C}^{5}\right)$. ${ }^{15} \mathrm{~N}$ NMR $\left(50.7 \mathrm{MHz}, \mathrm{DMSO}-d_{6}\right) \delta: 99.0\left(\mathrm{~N}^{10}\right), 186.9\left(\mathrm{~N}^{7}\right), 190.6\left(\mathrm{~N}^{1}\right)$, $272.2\left(\mathrm{~N}^{2}\right), 274.6\left(\mathrm{~N}^{8}\right)$. HRMS (ESI), $m / z: 318.1357[\mathrm{M}-\mathrm{H}]^{-}$(calc. for $\left.\mathrm{C}_{18} \mathrm{H}_{16} \mathrm{~N}_{5} \mathrm{O}, \mathrm{m} / z: 318.1360\right)$.

$\mathrm{N}^{\prime}-\{(\mathrm{Z})$-[3-Methyl-1-(4-nitrophenyl)-5-oxo-1H-pyrazol-4(5H)-ylidene]methyllbenzohydrazonamide 5b. Yield 35-40\%, mp 138-139 ${ }^{\circ} \mathrm{C}$ (decomp.). ${ }^{1} \mathrm{H}$ NMR (400 MHz, DMSO- $\left.d_{6}\right) \delta: 2.20$ (s, 3 H, Me), $7.23(\mathrm{~s}, 1 \mathrm{H}, \mathrm{CH})$, 7.60-7.70 (m, 2H, $\left.\mathrm{CH}_{\text {arom }}\right), 7.70-7.80\left(\mathrm{~m}, 1 \mathrm{H}, \mathrm{CH}_{\text {arom }}\right), 7.90-7.97(\mathrm{~m}$, $\left.2 \mathrm{H}, \mathrm{CH}_{\text {arom }}\right), 8.21\left(\mathrm{~d}, 2 \mathrm{H}, \mathrm{CH}_{\text {arom }}, J 8.0 \mathrm{~Hz}\right), 8.26\left(\mathrm{~d}, 2 \mathrm{H}, \mathrm{CH}_{\text {arom }}, J 8.0 \mathrm{~Hz}\right)$, $8.65(\mathrm{~s}, 1 \mathrm{H}, \mathrm{NH}), 9.16(\mathrm{~s}, 1 \mathrm{H}, \mathrm{NH})$. HRMS (ESI), $m / z: 365.1326[\mathrm{M}+\mathrm{H}]^{+}$ (calc. for $\mathrm{C}_{18} \mathrm{H}_{17} \mathrm{~N}_{6} \mathrm{O}_{3}, m / z: 365.1357$ ). is confirmed by direct connectivities in the ${ }^{1} \mathrm{H}_{-}{ }^{15} \mathrm{~N}$ HMQC spectrum. A signal of another $\mathrm{NH}$ proton is observed in very low field at $\delta_{\mathrm{H}} 17.46 \mathrm{ppm}$ indicative of a strong intramolecular hydrogen bond. It has also been justified by a ${ }^{1} \mathrm{H}_{-}{ }^{15} \mathrm{~N}$ HMQC experiment that this proton is bound to the $\mathrm{N}^{7}$ atom $\left(\delta_{\mathrm{N}} 186.9 \mathrm{ppm}\right) .{ }^{1} \mathrm{H}-{ }^{13} \mathrm{C}$ HMBC 2D experiment (Figure 2), shows that $\mathrm{H}^{7}$ proton has coupling constants through two or three bonds with the $\mathrm{C}^{9}\left(\delta_{\mathrm{C}} 156.35 \mathrm{ppm}\right)$ and $\mathrm{C}^{6}\left(\delta_{\mathrm{C}} 145.30 \mathrm{ppm}\right)$ carbon atoms, while the $\mathrm{H}^{10 \mathrm{a}}$ and $\mathrm{H}^{10 \mathrm{~b}}$ protons have coupling constants with the $\mathrm{C}^{9}$ and $\mathrm{C}^{1 \text { " carbon atoms }}$ $\left(\delta_{\mathrm{C}} 127.82 \mathrm{ppm}\right)$. The $\mathrm{H}^{6}$ proton manifests long-range correlations with the $\mathrm{C}^{3}\left(\delta_{\mathrm{C}} 148.50 \mathrm{ppm}\right), \mathrm{C}^{4}\left(\delta_{\mathrm{C}} 98.29 \mathrm{ppm}\right)$ and $\mathrm{C}^{5}$ carbon atoms $\left(\delta_{\mathrm{C}} 161.56 \mathrm{ppm}\right)$ in the ${ }^{1} \mathrm{H}^{-1}{ }^{13} \mathrm{C}$ HMBC spectrum, as well as with the $\mathrm{N}^{7}\left(\delta_{\mathrm{N}} 186.9 \mathrm{ppm}\right)$ and $\mathrm{N}^{8}$ nitrogen atoms $\left(\delta_{\mathrm{N}} 274.6 \mathrm{ppm}\right)$ in the ${ }^{1} \mathrm{H}_{-}{ }^{15} \mathrm{~N}$ HMBC spectrum.
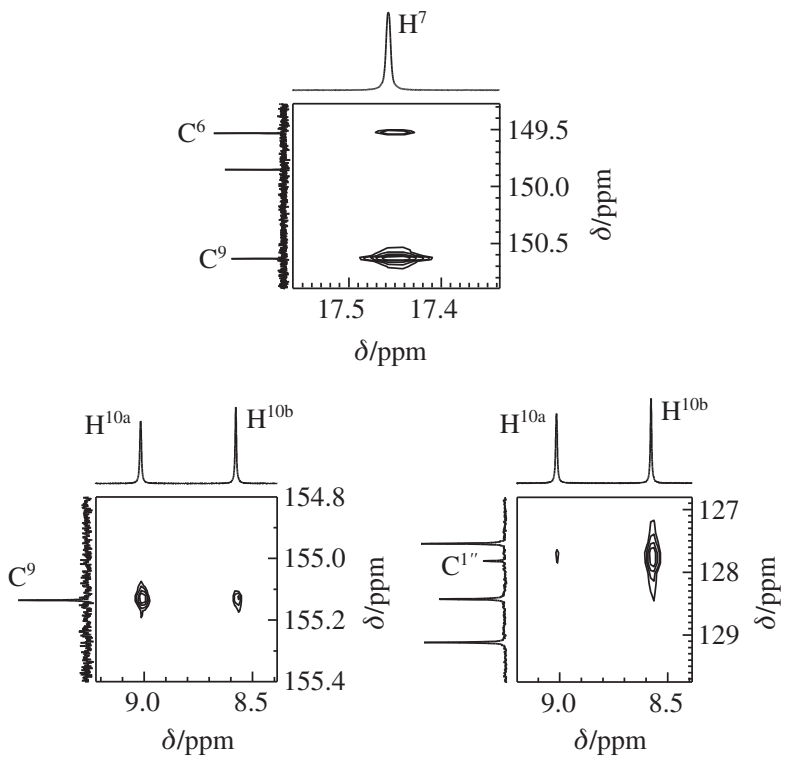

Figure 2 Fragment of a $2 \mathrm{D}^{1} \mathrm{H}^{-13} \mathrm{C}$ HMBC spectrum (500 MHz, DMSO- $d_{6}$ ) of compound $\mathbf{5 a}$. 
The signals of two nonequivalent protons at $\mathrm{N}^{10}$ typical of amidrazones $\mathbf{5}$ are also observed in the ${ }^{1} \mathrm{H}$ NMR spectrum of compound $\mathbf{5 b}$ at $\delta 8.65$ and $9.16 \mathrm{ppm}$.

The mechanism of formation of tetrapyrazolyl ethane derivatives $\mathbf{4}$ from triazino derivative $\mathbf{1}$ is likely to be similar to that of the previously reported ${ }^{5}$ reactions of quinoxaline with 3-methyl1-phenylpyrazol-5-one (see Scheme 2). The formation of amidrazones 5 presumably occurs as initial attack of the pyrazolone to $\mathrm{C}^{6}$ and hydroxyl addition to $\mathrm{C}^{5}$, which is followed by cleavage of the $\mathrm{N}^{1}-\mathrm{C}^{6}$ bond in intermediates $\mathbf{A}$, oxidation of the aldehyde group in intermediates $\mathbf{B}$ and decarboxylation of the resulting acid.

The formation of amidrazones $\mathbf{5}$ can also be assumed to proceed through an alternative pathway which involves a nucleophilic attack of the pyrazolone to the $\mathrm{C}^{5}$ atom and the hydroxyl to the $\mathrm{C}^{6}$ atom. Accordingly, it is assumed in this case that elimination of the $\mathrm{C}^{6}$ atom of the triazine ring occurs.

To conclude, depending on the nature of the attacking nucleophile, 3-phenyl-1,2,4-triazine 1 either gives stable 5- $\sigma$-adducts (the reaction with dimedone) or formally acts as a two-carbon synthon which 'cross-links' four molecules of 3-methyl-1-phenyl- pyrazol-5-ones. Furthermore, it is likely that competitive reactions of triazine 1 with pyrazolone and water result in simultaneous cleavage of the triazine ring with elimination of one carbon atom and formation of stable acyclic amidrazones.

\section{References}

1 H. Neunhoeffer and P. F. Wiley, Chemistry of 1,2,3-Triazines, 1,2,4-Triazines, Tetrazines and Pentazines, Wiley, New York, 1978.

2 S. Konno, S. Ohba, M. Sagi and H. Yamanaka, Chem. Pharm. Bull., 1987, 35, 1378.

3 S. G. Alekseev, V. N. Charushin, O. N. Chupakhin, S. V. Shorshnev, A. I. Chernyshev and N. A. Klyuev, Chem. Heterocycl. Compd., 1986, 22, 1242 (Khim. Geterotsikl. Soedin., 1986, 1535).

4 S. G. Alexeev, V. N. Charushin and O. N. Chupakhin, Tetrahedron Lett., 1988, 29, 1431

5 Yu. A. Azev, E. D. Oparina, I. S. Kovalev, P. A. Slepukhin and R. K. Novikova, Mendeleev Commun., 2012, 22, 37.

Received: 2nd July 2013; Com. 13/4147 